Recep Dokuyucu ${ }^{1}$

Ali Bilgili ${ }^{2}$

Basak Hanedan ${ }^{3}$

Hatice Dogan ${ }^{1}$

Ahmet Dokuyucu ${ }^{4}$

Muhammet Murat Celik

\title{
ATTENUATING EFFECTS OF CAFFEIC ACID PHENETHYL ESTER WITH INTRALIPID ON HEPATOTOXICITY OF CHLORPYRIFOS IN THE CASE OF RATS
}

\author{
ŁAGODZACCE DZIAŁANIE ESTRU FENETYLOWEGO KWASU KAWOWEGO Z INTRALIPIDEM \\ NA HEPATOTOKSYCZNOŚĆ CHLOROPYRIFOSU U SZCZURÓW
}

\author{
${ }^{1}$ Mustafa Kemal University, Hatay, Turkey \\ Faculty of Medicine, Department of Physiology \\ ${ }^{2}$ Ankara University, Ankara, Turkey \\ Faculty of Veterinary Medicine, Department of Pharmacology and Toxicology \\ ${ }^{3}$ Ataturk University, Erzurum, Turkey \\ Faculty of Veterinary Medicine, Department of Internal Medicine \\ ${ }^{4}$ Lumina - The University of South-East Europe, Bucharest, Romania \\ Faculty of Mathematics and Computer Science, Department of Information Technology \\ ${ }^{5}$ Mustafa Kemal University, Hatay, Turkey \\ Faculty of Medicine, Department of Internal Medicine
}

\begin{abstract}
Background: Chlorpyrifos (CPF), insecticide widely used in agriculture, may cause poisonings in the case of humans. As a result, there is a large amount of treatment research underway to focus on the possibility of chlorpyrifos induced poisonings. The aim of this study has been to evaluate the effects of caffeic acid phenethyl ester (CAPE) and intralipid (IL) on hepatotoxicity induced by chlorpyrifos in the case of rats. Material and Methods: The rats in this study were treated with CPF (10 mg/kg body weight (b.w.), orally), CAPE (10 $\mu \mathrm{mol} / \mathrm{kg}$ b.w., intraperitoneally), IL (18.6 ml $/ \mathrm{kg}$ b.w., orally), CPF+CAPE, CPF+IL, and CPF+CAPE+IL. The plasma total oxidant capacity (TOC), total antioxidant capacity (TAC) were measured and the oxidative stress index (OSI) was calculated. Liver histopathology and immunohistochemical staining were performed. Results: Chlorpyrifos statistically significantly decreased the TAC levels in the rats' plasma and increased the apoptosis and the TOC and OSI levels. In the chlorpyrifos induced liver injury, CAPE and CAPE+IL significantly decreased the plasma OSI levels and the apoptosis, and significantly increased the plasma TAC levels. Conclusions: This study revealed that CAPE and CAPE+IL attenuate chlorpyrifos induced liver injuries by decreasing oxidative stress and apoptosis. Med Pr 2016;67(6):743-749
\end{abstract}

Key words: apoptosis, oxidative stress, liver, rats, chlorpyrifos, caffeic acid phenethyl ester

\section{STRESZCZENIE}

Wstęp: Chloropiryfos (CPF), środek owadobójczy szeroko stosowany w rolnictwie, może powodować zatrucia u ludzi. Z tego powodu prowadzi się wiele badań dotyczących możliwości leczenia zatrucia chloropiryfosem. Celem pracy była ocena wpływu estru fenetylowego kwasu kawowego (caffeic acid phenethyl ester - CAPE) i intralipidu (IL) na uszkodzenia wątroby u szczurów wywołane przez chloropiryfos. Materiał i metody: Szczurom podawano CPF (10 mg/kg masy ciała (mc.), doustnie), CAPE (10 $\mu \mathrm{mol} / \mathrm{kg} \mathrm{mc}$., dootrzewnowo), IL (18,6 ml/kg mc., doustnie), CPF+CAPE, CPF+IL oraz CPF+CAPE+IL. Zmierzono całkowitą zdolność utleniającą (total oxidant capacity - TOC) i całkowita zdolność przeciwutleniająca (total antioxidant capacity - TAC) osocza krwi i obliczono wskaźnik stresu oksydacyjnego (oxidative stress index - OSI). U zwierząt wykonano także badanie histopatologiczne i barwienie immunohistochemiczne tkanek wątroby. Wyniki: Chloropiryfos istotnie zmniejszał u badanych szczurów TAC osocza, a zwiększał apoptozę, TOC i OSI. Natomiast CAPE i CAPE+IL istotnie zmniejszały OSI osocza i apoptozę, a zwiększały TAC osocza u szczurów z uszkodzeniami wątroby wywołanymi przez chloropiryfos. Wnioski: Badanie wykazało, że CAPE i CAPE+IL poprzez zmniejszenie stresu oksydacyjnego i apoptozy redukują u szczurów uszkodzenia wątroby wywołane przez chloropiryfos. Med. Pr. 2016;67(6):743-749

Słowa kluczowe: apoptoza, stres oksydacyjny, wątroba, szczury, chloropyrifos, ester fenetylowy kwasu kawowego

Corresponding author / Autor do korespondencji: Recep Dokuyucu, Mustafa Kemal University, Faculty of Medicine, Department of Physiology, Hatay Street 2, Serinyol, 31040 Antakya, Hatay, Turkey, e-mail: drecepfatih@gmail.com Received: February 5, 2016, accepted: July 8, 2016 


\section{INTRODUCTION}

Chlorpyrifos (CPF), an organophosphate (OP) compound, is commonly used against insects in agriculture and on animal farms [1]. However, indiscriminate applications of the pesticides may result in environmental pollution and human and animal poisonings [2]. Organophosphate induced poisonings may occur by inhalation, cutaneous absorption, or ingestion [3]. Inhibition of acetylcholinesterase activity and accumulation of excess acetylcholine at the nerve endings may lead to muscarinic and nicotinic clinical signs $[2,4]$. Toxic clinical signs induced by OP poisonings may also develop through the occurrence of oxidative stress $[5,6]$. Several studies have reported that OP compounds may cause various organ injuries and oxidative stress [3,7-9].

Caffeic acid phenethyl ester (CAPE) is one of active components of propolis that is a honey bee product [10]. Traditional medicine takes advantage of propolis as a dietary supplement for therapeutic aims. It has neuroprotective, hepatoprotective and cardioprotective activities with anti-inflammatory and anti-oxidative effects [11,12].

Approved for parenteral nutrition, intravenous lipid emulsion (ILE) has become a focus of interest in the treatment of lipophilic drug toxicities [13]. Intravenous lipid emulsion has been reported to successfully treat the toxicity of local anesthetics, calcium channel blockers, $\beta$-blockers, and a variety of psychotropic agents $[14,15]$. However, the mechanism of ILE action has not yet been explored thoroughly [15]. Further research still remains to be conducted in order to discover whether or not ILE is safe to use for treating toxicity from chlorpyrifos.

The need for additional research concerning the possibility of OP poisoning is also important, especially in view of the fact that 3 million acute poisoning cases are reported worldwide every year $[16,17]$. The aim of this study has been to evaluate the effects of caffeic acid phenethyl ester and intralipid on hepatotoxicity induced by chlorpyrifos in the case of rats.

\section{MATERIAL AND METHODS}

\section{Animals}

The current study was approved by Necmettin Erbakan University and the Experimental Animal Ethics Committee in Konya, Turkey, with the ethic No. 2012/057. The animal material consisted of 49 adult Wistar albino rats, each weighing $200-250 \mathrm{~g}$. They were kept in stand- ard housing facilities at room temperature of $21 \pm 2^{\circ} \mathrm{C}$, in a 12-h light-dark cycle. The experimental protocol was carried out according to the International Guidelines for the Care and Use of Laboratory Animals.

\section{Experimental process}

The rats were randomly divided into 7 groups of 7 rats each, as follows:

1. The control group.

2. The chlorpyrifos (CPF) group was treated with CPF $10 \mathrm{mg} / \mathrm{kg}$ body weight (b.w.), orally [4].

3. The intralipid (IL) group was treated with IL $18.6 \mathrm{ml} / \mathrm{kg}$ b.w., orally [18].

4. The caffeic acid phenethyl ester (CAPE) group was treated with CAPE $10 \mu \mathrm{mol} / \mathrm{kg}$ b.w., intraperitoneally [19].

5. The $\mathrm{CPF}+\mathrm{IL}$ group was treated with $\mathrm{CPF}$ and IL.

6. The $\mathrm{CPF}+\mathrm{CAPE}$ group was treated with $\mathrm{CPF}$ and CAPE.

7. The $\mathrm{CPF}+\mathrm{CAPE}+\mathrm{IL}$ group was treated with CPF, CAPE, and IL.

The single dose treatments were made with CPF, IL, and CAPE. The rats were treated with CPF, immediately followed by IL and/or CAPE.

\section{Sample collection}

The rats were sacrificed using ketamine $(50 \mathrm{mg} / \mathrm{kg}$ b.w. intraperitoneal (i.p.), Ketalar, Parke Davis, Turkey) and xylazine $(5 \mathrm{mg} / \mathrm{kg}$ b.w., i.p., Rompun, Bayer AG, Germany) immediately after the administration of the drugs. The plasma samples of the rats had been removed, centrifuged and stored at $-70^{\circ} \mathrm{C}$ until they were used for biochemical analysis. The liver tissues were stored in a formaldehyde solution for histopathological examination purposes.

\section{Total antioxidant capacity (TAC)}

\section{and total oxidant capacity (TOC) analysis}

The TAC and TOC levels of plasma samples were measured by a commercial test kit (Rel Assay Diagnostics, Turkey). The TAC was measured by a novel automated and colorimetric method developed by Erel [20]. In this method, mixing reagent 1 (xylenol orange $150 \mu \mathrm{M}$, $\mathrm{NaCl} 140 \mathrm{mM}$ and glycerol $1.35 \mathrm{M}$ in $25 \mathrm{mM} \mathrm{H}_{2} \mathrm{SO}_{4}$ solution, $\mathrm{pH}$ 1.75) and reagent 2 (ferrous ion $5 \mathrm{mM}$ and o-dianisidine $10 \mathrm{mM}$ in $25 \mathrm{mM} \mathrm{H}_{2} \mathrm{SO}_{4}$ solution) produced hydroxyl radicals, which converted o-dianisidine molecules into dianisidyl radicals, resulting in a bright yellow-brown color. After adding the supernatant, the antioxidants of the supernatant suppressed 
further color development. The TAC in the supernatant was measured spectrophotometrically, with lower than $3 \%$ precision values. The data of the TAC is expressed as mmol Trolox equivalent/l for the plasma. Erel's method [21] was also used for measuring the plasma TOC levels.

The conversion of the ferrous ion-o-dianisidine complex to a ferric ion was provided by the oxidants of the supernatant; glycerol molecules of the reaction medium conducted this oxidation reaction. A colored complex with xylenol orange was produced by the ferric ion. The oxidant molecules in the supernatant were measured spectrophotometrically with color intensity. The data of the TOC is expressed as mmol $\mathrm{H}_{2} \mathrm{O}_{2}$ equivalent/l for plasma. The calculation of the oxidative stress index (OSI) was made by the percent ratio of the TOC to the TAC (OSI (arbitrary unit $)=$ TOC $\left(\mathrm{mmol} \mathrm{H}_{2} \mathrm{O}_{2}\right.$ equivalent/l)/TAC (mmol Trolox equivalent/l)) [9].

\section{Histopathological analysis}

The fixed liver tissues were embedded in paraffin. Four $\mu \mathrm{m}$-thick sections were cut from paraffin blocks using microtome (Leica Rotary, Leica Microsystems GmbH, Germany), stained with hematoxyline and eosin (HE) and examined under a light microscope $(\times 100)$. The liver tissue injury was scored $0-3$ : with none or mild changes (0); mild cytoplasmic vacuolization, and nuclear pyknosis (1); moderate nuclear pyknosis, cytoplasmic hypereosinophilia, and intercellular adhesion loss (2); severe hemorrhage, neutrophil infiltration, intercellular adhesion loss, and necrosis (3).

\section{Immunohistochemistry}

The immunohistochemistry process was performed using a Leica Bond-Max automated IHC/ISH platform (Leica Microsystems Inc., USA). The liver sections were dewaxed in a Bond Dewax solution and rehydrated in alcohol and a Bond Wash solution (Leica Microsystems Inc., USA). Retrieval of the antigen was carried out using a high $\mathrm{pH}$ (ER2) retrieval solution for $15 \mathrm{~min}$; next, the sections were blocked using peroxidase for $5 \mathrm{~min}$ on the machine. An anti-mouse monoclonal antibody Bcl-2 (C-2, sc-7382 (Santa Cruz Biotechnology Inc., USA) in dilution 1:200), an anti-mouse monoclonal antibody Bax (B-9, sc-7480 (Santa Cruz Biotechnology Inc., USA) in dilution 1:100), and an anti-mouse caspase 3 (CPP32) monoclonal antibody (clone JHM62 (Leica Biosystems Ltd., Great Britain) in dilution 1:50) were applied for $60 \mathrm{~min}$ at room temperature. Detection was complied with using the Bond Polymer Refine Red Detection system (Leica Microsystems GmbH, Germany). The liver apoptosis was evaluated in 10 randomly selected microscope fields under $\times 400$ magnification.

\section{Statistical analysis}

The statistical analysis of the data in the Statistical Package for the Social Sciences (SPSS) package program (version 12, SPSS, USA) was performed by means of a oneway ANOVA. Post-hoc Tukey and Dunnett T3 tests were used for comparing the studied groups. The differences were considered significant if $\mathrm{p}<0.05$.

\section{RESULTS}

\section{TAC levels}

There was no significant difference in the plasma TAC level between the control group and the IL, $\mathrm{CAPE}, \mathrm{CPF}+\mathrm{CAPE}$, and $\mathrm{CPF}+\mathrm{CAPE}+\mathrm{IL}$ groups. The plasma TAC level in the CPF group was significantly decreased in comparison to that of the control, IL, $\mathrm{CAPE}, \mathrm{CPF}+\mathrm{CAPE}$, and $\mathrm{CPF}+\mathrm{CAPE}+\mathrm{ILgroups}(\mathrm{p}<0.05)$. There was no significant difference in the TAC level between the CPF group and the CPF+IL group (Table 1).

\section{TOC levels}

The plasma TOC level was significantly increased in the CPF group as compared to the control, IL, CAPE, CPF+CAPE, and CPF+CAPE+IL groups $(\mathrm{p}<0.05)$. There was no significant difference in the TOC level between the control group and the IL, $\mathrm{CAPE}, \mathrm{CPF}+\mathrm{IL}, \mathrm{CPF}+\mathrm{CAPE}$, and $\mathrm{CPF}+\mathrm{CAPE}+\mathrm{IL}$ groups (Table 1).

\section{OSI levels}

There was no significant difference in the OSI level between the control group and the IL, CAPE, CPF+CAPE, and $\mathrm{CPF}+\mathrm{CAPE}+\mathrm{IL}$ groups. The plasma OSI level was significantly increased in the CPF and CPF+IL groups as compared to the control group ( $\mathrm{p}<0.05)$. There was no significant difference in the plasma OSI level between the CPF group and the CPF+IL group, and there was a significant difference in the OSI level between the CPF group and the control, IL, CAPE, CPF+CAPE, and CPF+CAPE+IL groups $(\mathrm{p}<0.05)$ (Table 1).

\section{Histopathological evaluation}

Nuclear pyknosis, cytoplasmic hypereosinophilia, cytoplasmic vacuolization, and intercellular adhesion loss were not observed in the control (Photo 1a), 
Table 1. Effects of caffeic acid phenethyl ester (CAPE) and intralipid (IL) on hepatotoxicity of chlorpyrifos (CPF) in rats Tabela 1. Wpływ estru fenetylowego (CAPE) i intralipidu (IL) na hepatotoksyczność chloropiryfosu (CPF) u szczurów

\begin{tabular}{|c|c|c|c|c|c|c|c|}
\hline \multirow{2}{*}{$\begin{array}{l}\text { Parameter } \\
\text { Parametr }\end{array}$} & \multicolumn{7}{|c|}{$\begin{array}{l}\text { Study group } \\
\text { Grupa badana }\end{array}$} \\
\hline & $\begin{array}{l}\text { control } \\
\text { kontrolna } \\
(\mathrm{N}=7)\end{array}$ & $\begin{array}{l}\mathrm{CPF} \\
(\mathrm{N}=7)\end{array}$ & $\begin{array}{c}\mathrm{IL} \\
(\mathrm{N}=7)\end{array}$ & $\begin{array}{l}\text { CAPE } \\
(\mathrm{N}=7)\end{array}$ & $\begin{array}{c}\mathrm{CPF}+\mathrm{IL} \\
(\mathrm{N}=7)\end{array}$ & $\begin{array}{c}\mathrm{CPF}+\mathrm{CAPE} \\
(\mathrm{N}=7)\end{array}$ & $\begin{array}{c}\mathrm{CPF}+\mathrm{CAPE}+\mathrm{IL} \\
(\mathrm{N}=7)\end{array}$ \\
\hline TAC $[\mathrm{mmol} / \mathrm{l}](\mathrm{M} \pm \mathrm{SEM})$ & $1.00 \pm 0.04$ & $0.66 \pm 0.02^{\mathrm{a}}$ & $1.04 \pm 0.02$ & $1.11 \pm 0.04$ & $0.69 \pm 0.01^{\mathrm{a}}$ & $0.83 \pm 0.03$ & $0.96 \pm 0.04$ \\
\hline TOC [mmol/l] $(\mathrm{M} \pm \mathrm{SEM})$ & $43.06 \pm 2.62$ & $58.82 \pm 3.85^{\mathrm{a}}$ & $43.26 \pm 1.90$ & $38.51 \pm 2.29$ & $54.87 \pm 2.90$ & $46.88 \pm 2.98$ & $46.40 \pm 2.44$ \\
\hline OSI (TOC/TAC) (M \pm SEM) & $42.98 \pm 1.79$ & $89.64 \pm 6.76^{a}$ & $41.65 \pm 1.82$ & $34.73 \pm 1.91$ & $79.44 \pm 4.37^{\mathrm{a}}$ & $56.80 \pm 5.06$ & $48.37 \pm 2.94$ \\
\hline $\mathrm{HP}(\mathrm{M} \pm \mathrm{SEM})$ & $3.14 \pm 0.50$ & $14.85 \pm 1.14^{\mathrm{a}}$ & $6.00 \pm 0.30$ & $4.00 \pm 0.21$ & $11.42 \pm 0.71^{\mathrm{a}}$ & $8.28 \pm 0.74$ & $8.42 \pm 0.64$ \\
\hline IHC $(\mathrm{M} \pm$ SEM $)$ & $16.71 \pm 1.30$ & $145.42 \pm 2.75^{\mathrm{b}}$ & $15.14 \pm 0.79$ & $13.42 \pm 0.71$ & $127.00 \pm 1.79$ & $78.85 \pm 1.38$ & $66.00 \pm 2.71$ \\
\hline
\end{tabular}

TAC - total antioxidant capacity / całkowita zdolność przeciwutleniająca, TOC - total oxidant capacity / całkowita zdolność utleniająca, OSI - oxidative stress index / wskaźnik stresu oksydacyjnego, HP - histopathology / badanie histopatologiczne, IHC - immunohistochemistry / badanie immunohistochemiczne. M - mean / średnia, SEM - standard error of the mean / błą standardowy średniej.

${ }^{a} \mathrm{p}<0.05$ vs. the control, IL, CAPE, CPF+CAPE, and CPF+CAPE+IL group / $\mathrm{p}<0,05$ vs grupa kontrolna, IL, CAPE, CPF+CAPE i CPF+CAPE+IL.

${ }^{\mathrm{b}} \mathrm{p}<0.05$ vs. the control, IL, CAPE, CPF+IL, CPF+CAPE, and CPF+CAPE+IL group / $\mathrm{p}<0,05$ vs grupa kontrolna, IL, CAPE, CPF+IL, CPF+CAPE i CPF+CAPE+IL.

a)

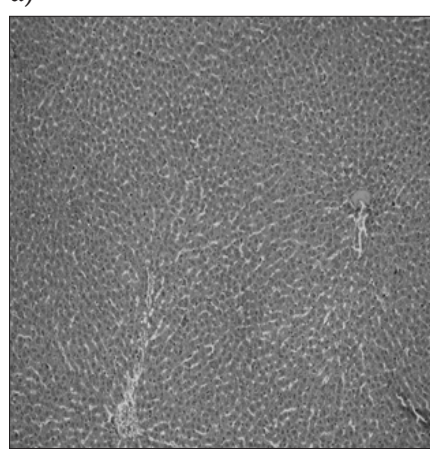

d)

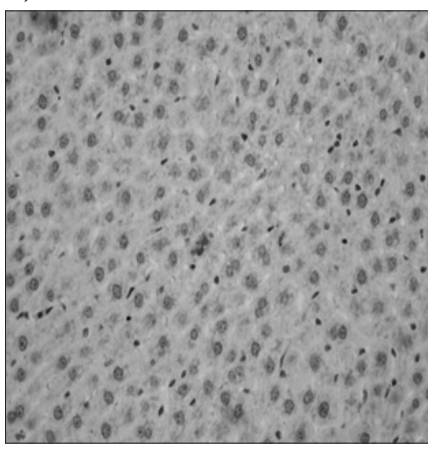

b)

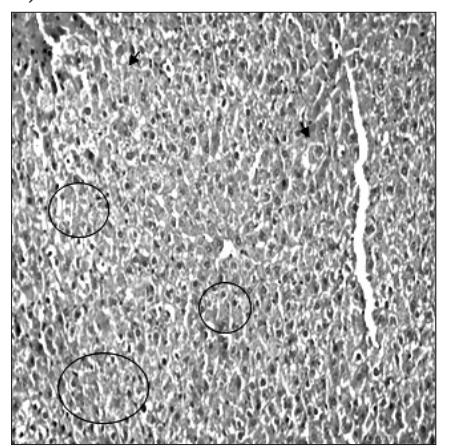

e)

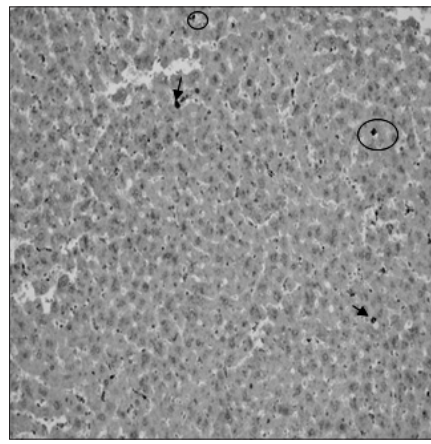

c)

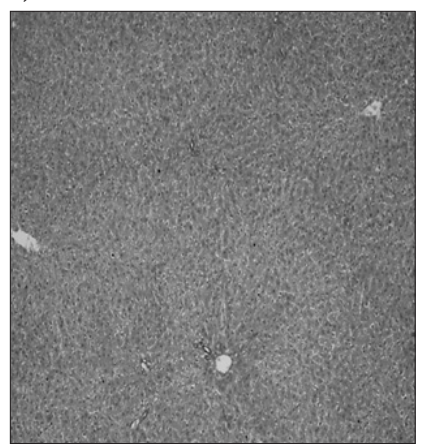

f)

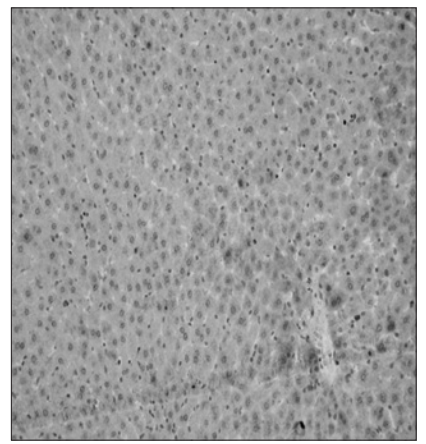

a) control group - normal liver histology (image magnification $\times 200$ ) / grupa kontrolna - wynik badania histologicznego wątroby w normie (powiększenie obrazu $\times 200$ ), b) CPF group - severe liver damage and necrosis (indicated by the arrows and circles) ( $\times 200)$ / grupa CPF - poważne uszkodzenia i martwica wątroby (zaznaczone strzałkami i kółkami) (×200), c) CPF+CAPE+IL group - regressive regeneration including regenerative changes suggestive of normal liver histology and focal cytoplasmic hypereosinophilia $(\times 200)$ / grupa CPF+CAPE+IL - regresywna regeneracja, w tym zmiany regeneracyjne wskazujące na wynik badania histologicznego wątroby w normie i ogniskową cytoplazmatyczną hipereozynofilię $(\times 200)$, d) control group - immunoreactivity as opposed to the control group $(\times 200)$ / grupa kontrolna - immunoreaktywność w porównaniu z grupą kontrolną $(\times 200)$, e) CPF group - immunoreactivity suggesting increased apoptosis in the liver tissues (indicated by the arrows and circles) ( $\times 400) /$ grupa CPF - immunoreaktywność wskazująca na zwiększoną apoptozę w tkankach wątroby (zaznaczoną strzałkami i kółkami) ( $\times 400)$, f) CPF+CAPE+IL group - apoptosis level was only lower than the one in the CPF group $(\times 400)$ / grupa CPF+CAPE+IL - poziom apoptozy niższy tylko w porównaniu z grupą CPF $(\times 400)$. Abbreviations as in Table 1 / Skróty jak w tabeli 1.

Photo 1. Liver tissues of rats studied under light microscope $(a-c)$ using hematoxyline and eosin (HE) stain and (d-f) immunohistochemical (IHC) method

Fot. 1. Tkanki wątroby szczura badane pod mikroskopem optycznym (a-c) po barwieniu hematoksyliną i eozyną (HE) (d-f) po zastosowaniu metody immunohistochemicznej (IHC) 
IL, and CAPE groups. Severe hemorrhage, neutrophil infiltration, nuclear pyknosis, cytoplasmic hypereosinophilia, cytoplasmic vacuolization, intercellular adhesion loss, and necrosis were observed in the CPF group (Photo $1 \mathrm{~b}$ ). These severe hemorrhage, neutrophil infiltration, intercellular adhesion loss, and necrosis changes were significantly decreased in the $\mathrm{CPF}+\mathrm{CAPE}$ and $\mathrm{CPF}+\mathrm{CAPE}+\mathrm{IL}$ groups as compared to the $\mathrm{CPF}$ group (Table $1, \mathrm{p}<0.05$, Photo $1 \mathrm{c}$ ). There was no significant difference in these changes between the CPF group and the $\mathrm{CPF}+\mathrm{IL}$ group.

\section{Immunohistochemistry evaluation}

Immunohistochemistry showed significantly increased apoptosis in the liver tissues of the CPF group as compared to the control group (Photo $1 \mathrm{~d}$ and 1e) and significantly decreased apoptosis in the $\mathrm{CPF}+\mathrm{CAPE}$ and $\mathrm{CPF}+\mathrm{CAPE}+\mathrm{IL}$ groups as compared to the $\mathrm{CPF}$ group. The significant decrease in the apoptosis was determined in the $\mathrm{CPF}+\mathrm{CAPE}+\mathrm{IL}$ group (Photo 1f). The apoptosis decrease in the CPF+CAPE group and the $\mathrm{CPF}+\mathrm{CAPE}+\mathrm{IL}$ group was significantly higher than in the CPF+IL group $(\mathrm{p}<0.05)$.

\section{DISCUSSION}

Organophosphates cause oxidative stress by altering the balance between the production of oxidants and antioxidants [2]. The chlorpyrifos exposure in the case of rats has been reported to cause peroxidative damage in various tissues by enhancing lipid peroxidation products [22]. In this study, the plasma TOC and OSI levels in the case of rats were significantly increased in the CPF group as compared to the control group. This result suggests that a single oral dose of the CPF (10 mg/kg b.w.) induces oxidative stress in the plasma of rats. The oxidative stress induced by rats' exposure to the CPF in this study has also been reported in other similar studies carried out for mice or rats $[7,22-24]$.

The mechanism of OP compounds that produce oxidative stress has been involved with their metabolism by the cytochrome P450 [22]. To counteract the oxidative stress, the plasma TAC levels regarding the acute CPF toxicity of the CPF group in the case of rats have been found to significantly decrease as compared to the control group. In the event of the CPF induced toxicity, various studies have found that antioxidant activity increases or decreases depending on the amounts of the CPF doses and the durations of the treat- ment $[3,16,23]$. The decreased TAC levels induced by the acute $\mathrm{CPF}$ toxicity may suggest the consumption of the TAC due to significantly increased plasma OSI levels.

Research continues to be conducted to find a way to reduce the oxidative stress responsible for the pathogenesis of OP compounds. For this purpose, an anti-inflammatory agent such as rosiglitazone [25], antioxidants agents such as vitamin C [23], N-acetylcystein [26], melatonin [27], quercetin [8], pomegranate, and rutin [28] have been reported as the attenuating agents for $\mathrm{CPF}$ induced toxicity.

For the first time has this study revealed the attenuating effects of the CAPE and CAPE+IL treatment on oxidative stress and apoptosis in the CPF induced liver toxicity of rats. Caffeic acid phenethyl ester is known to have neuroprotective, hepato-protective, and cardio-protective activities with anti-inflammatory and anti-oxidative effects $[11,12,29]$, and the ILE has become a focus of interest in the treatment of lipophilic drug toxicities [15]. Caffeic acid phenethyl ester and the CAPE+IL have been reported to be effective in attenuating the renal toxicity induced by dichlorvos that is an OP compound [9]. In this study, the CAPE and CAPE+IL treatment provided a significant increase in the plasma TAC levels against the CPF induced liver toxicity. However, the IL alone could not significantly increase the plasma TAC levels in the CPF toxicity of rats.

Membrane lipids, membrane receptors, and membrane-bound enzymes may be affected by lipid peroxidation and by altering the membrane function, fluidity, and structure [30]. Organophosphates may induce injuries in various organs and cells $[3,7-9,24]$. The exhibited histopathological changes due to the CPF induced liver toxicity were attenuated by the CAPE and CAPE+IL treatment, but not by exclusively the IL treatment.

The chlorpyrifos induced cellular toxicity leads to oxidative stress [25], caspase- 3 activation and subsequent increased release of cytochrome $c$ into the $c y-$ tosol [26]. Mitochondrial dysfunction induces oxidative stress, deoxyribonucleic acid (DNA) damage, and apoptosis [26].

\section{CONCLUSIONS}

This study revealed that cell death caused by the CPF in the liver of rats is involved in apoptosis through increased OSI levels and activated caspase-3. Caffeic acid phenethyl ester and the CAPE+IL treatment attenuated apoptosis by inhibiting caspase- 3 activation in the rats with exposure to the CPF. The most effective 
caspase-3 inhibition was provided by the CAPE+IL treatment. This study suggests that the CAPE and CAPE+IL treatment may attenuate the CPF induced liver injury by decreasing oxidative stress and inhibiting caspase- 3 activation.

\section{REFERENCES}

1. Mansour SA, Mossa A-TH. Lipid peroxidation and oxidative stress in rat erythrocytes induced by chlorpyrifos and the protective effect of zinc. Pestic Biochem Physiol. 2009;93:34-9, http://dx.doi.org/10.1016/j.pestbp. 2008.09.004.

2. Dhouib IE-B, Lasram MM, Annabi A, Gharbi N, ElFazaa S. A comparative study on toxicity induced by carbosulfan and malathion in Wistar rat liver and spleen. Pestic Biochem Physiol. 2015;124:21-8, http://dx.doi. org/10.1016/j.pestbp.2015.03.012.

3. Lukaszewicz-Hussain A. Involvement of oxidative stress in liver injury after subchronic intoxication with low doses of chlorpyrifos - Study on rats. Cent Eur J Med. 2013;8: 132-9, http://dx.doi.org/10.2478/s11536-012-0100-2.

4. Wolf C, Riffel M, Weyman G, Douglas M, Norman S. Telemetry-based field studies for assessment of acute and short-term risk to birds from spray applications of chlorpyrifos. Environ Toxicol Chem. 2010;29:1795-803, http://dx.doi.org/10.1002/etc.227.

5. Karami-Mohajeri S, Abdollahi M. Mitochondrial dysfunction and organophosphorus compounds. Toxicol Appl Pharmacol. 2013;270(1):39-44, http://dx.doi.org/ 10.1016/j.taap.2013.04.001.

6. Akyol S, Akbas A, Butun I, Toktas M, Ozyurt H, Sahin $S$, et al. Caffeic acid phenethyl ester (CAPE) as a remedial agent for reproductive functions and oxidative stress-based pathologies of gonads. J Intercult Ethnopharmacol. 2015:4;187-91, http://dx.doi.org/10.5455/ jice.20150402062823.

7. Mansour SA, Mossa A-TH. Oxidative damage, biochemical and histopathological alterations in rats exposed to chlorpyrifos and the antioxidant role of zinc. Pestic Biochem Physiol. 2010;96:14-23, http://dx.doi.org/10.1016/ j.pestbp.2009.08.008.

8. Demir F, Uzun FG, Durak D, Kalender Y. Subacute chlorpyrifos-induced oxidative stress in rat erythrocytes and the protective effects of catechin and quercetin. Pestic Biochem Physiol. 2011;99:77-81, http://dx.doi. org/10.1016/j.pestbp.2010.11.002.

9. Celik MM, Alp A, Dokuyucu R, Zemheri E, Ozkanli S, Ertekin F, et al. Protective effects of intralipid and caffeic acid phenethyl ester on nephrotoxicity caused by dichlo- rvos in rats. J Anal Methods Chem. 2015;2015:491406, http://dx.doi.org/10.1155/2015/491406.

10. Murtaza G, Karim S, Akram MR, Khan SA, Azhar S, Mumtaz A, et al. Caffeic acid phenethyl ester and therapeutic potentials. Biomed Res Int. 2014;2014:145342, http://dx.doi.org/10.1155/2014/145342.

11. Zhang P, Tang Y, Li N-G, Zhu Y, Duan J-A. Bioactivity and chemical synthesis of caffeic acid phenethyl ester and its derivatives. Molecules. 2014;19(10):16458-76, http://dx.doi.org/10.3390/molecules191016458.

12. Tolba MF, Azab SS, Khalifa AE, Abdel-Rahman SZ, Abdel-Naim AB. Caffeic acid phenethyl ester, a promising component of propolis with a plethora of biological activities: A review on its anti-inflammatory, neuroprotective, hepatoprotective, and cardioprotective effects. IUBMB Life. 2013;65:699-709, http://dx.doi. org/10.1002/iub.1189.

13. Ozcan MS, Weinberg G. Intravenous lipid emulsion for the treatment of drug toxicity. J Intensive Care Med. 2014;29: 59-70, http://dx.doi.org/10.1177/0885066612445978.

14. Cave G, Harvey M, Graudins A. Review article: Intravenous lipid emulsion as antidote: A summary of published human experience. Emerg Med Australas. 2011;23:12341, http://dx.doi.org/10.1111/j.1742-6723.2011.01398.x.

15. Cao D, Heard K, Foran M, Koyfman A. Intravenous lipid emulsion in the emergency department: A systematic review of recent literature. J Emerg Med. 2015;48:387-97, http://dx.doi.org/10.1016/j.jemermed.2014.10.009.

16. Galloway T, Handy R. Immunotoxicity of organophosphorous pesticides. Ecotoxicology. 2003;12(1):345-63, http://dx.doi.org/10.1023/A:1022579416322.

17. Chowdhary S, Bhattacharyya R, Banerjee D. Acute organophosphorus poisoning. Clin Chim Acta. 2014;431: 66-76, http://dx.doi.org/10.1016/j.cca.2014.01.024.

18. Li J, Xiong M, Alhashem HM, Zhang Y, Tilak V, Patel A, et al. Effects of prenatal propofol exposure on postnatal development in rats. Neurotoxicol Teratol. 2014;43:51-8, http://dx.doi.org/10.1016/j.ntt.2014.03.006.

19. Koksel O, Ozdulger A, Tamer L, Cinel L, Ercil M, Degirmenci U, et al. Effects of caffeic acid phenethyl ester on lipopolysaccharide-induced lung injury in rats. Pulm Pharmacol Ther. 2006;19:90-5, http://dx.doi.org/ 10.1016/j.pupt.2005.03.006.

20. Erel O. A novel automated method to measure total antioxidant response against potent free radical reactions. Clin Biochem. 2004;37:112-9, http://dx.doi.org/10.1016/ j.clinbiochem.2003.10.014.

21. Erel O. A new automated colorimetric method for measuring total oxidant status. Clin Biochem. 2005;38:110311, http://dx.doi.org/10.1016/j.clinbiochem.2005.08.008. 
22. Ojha A, Yaduvanshi SK, Srivastava N. Effect of combined exposure of commonly used organophosphate pesticides on lipid peroxidation and antioxidant enzymes in rat tissues. Pestic Biochem Physiol. 2011;99:148-56, http://dx.doi.org/10.1016/j.pestbp.2010.11.011.

23. Aly N, El-Gendy K, Mahmoud F, El-Sebae AK. Protective effect of vitamin $\mathrm{C}$ against chlorpyrifos oxidative stress in male mice. Pestic Biochem Physiol. 2010;97: 7-12, http://dx.doi.org/10.1016/j.pestbp.2009.11.007.

24. Attia AA, ElMazoudy RH, El-Shenawy NS. Antioxidant role of propolis extract against oxidative damage of testicular tisuue induced by insecticide chlorpyrifos in rats. Pestic Biochem Physiol. 2012;103:87-93, http://dx.doi. org/10.1016/j.pestbp.2012.04.002.

25. Lee JE, Park JH, Jang SJ, Koh HC. Rosiglitazone inhibits chlorpyrifos-induced apoptosis via modulation of the oxidative stress and inflammatory response in SH-SY5Y cells. Toxicol Appl Pharmacol. 2014;278(2):159-71, http:// dx.doi.org/10.1016/j.taap.2014.04.021.

26. Lee JE, Lim MS, Park JH, Park CH, Koh HC. Nuclear NF- $\mathrm{BB}$ contributes to chlorpyrifos-induced apoptosis through p53 signaling in human neural precursor cells. Neurotoxicology. 2014;42:58-70, http://dx.doi.org/ 10.1016/j.neuro.2014.04.001.
27. Umosen AJ, Ambali SF, Ayo JO, Mohammed B, Uchendu C. Alleviating effects of melatonin on oxidative changes in the testes and pituitary glands evoked by subacute chlorpyrifos administration in Wistar rats. Asian Pac J Trop Biomed. 2012;2(8):645-50, http://dx.doi.org/ 10.1016/S2221-1691(12)60113-0.

28. Panemangalore M, Bebe FN. Short- and long-term exposure to low levels of pesticide and flavonoid mixtures modify endogenous antioxidants in tissues of rats. J Environ Sci Health B. 2009;44(4):357-64, http://dx.doi.org/ $10.1080 / 03601230902801034$.

29. Yilmaz HR, Uz E, Yucel N, Altuntas I, Ozcelik N. Protective effect of caffeic acid phenethyl ester (CAPE) on lipid peroxidation and antioxidant enzymes in diabetic rat liver. J Biochem Mol Toxicol. 2004;18:234-8, http:// dx.doi.org/10.1002/jbt.20028.

30. Keller JN, Mattson MP. Roles of lipid peroxidation in modulation of cellular signaling pathways, cell dysfunctions and death in the nervous system. Rev Neurosci. 1998;9:105-16, http://dx.doi.org/10.1515/REVNEURO. 1998.9.2.105.

This work is available in Open Access model and licensed under a Creative Commons Attribution-NonCommercial 3.0 Poland License / Ten utwór jest dostępny w modelu open access na licencji Creative Commons Uznanie autorstwa - Użycie niekomercyjne 3.0 Polska - http://creativecommons.org/ licenses/by-nc/3.0/pl/deed.en. 